\title{
Impact of long-term liming on sandy soil phosphorus sorption properties
}

\begin{abstract}
The static fertilisation experiment conducted in Skierniewice (Central Poland) since 1923 investigates the effect of mineral fertilisation with lime (CaNPK) or without lime (NPK) on the accumulation and release of phosphorus in reference to phosphorus sorption properties in the sandy soil profile. In the case of application of same doses of mineral fertilisers, the content of total phosphorus was higher in NPK than CaNPK soil. Parameters related to sorption capacity and bonding energy from Langmuir and Freundlich model of P sorption were significantly lower in CaNPK than NPK soil profile. This was particularly caused by a lower content of poorly crystallised hydro(oxide) aluminium and iron forms in CaNPK than NPK soil. Higher content of oxideextractable and bioavailable phosphorus extracted with double lactate solution, dissolved reactive phosphorus in water solution as well as degree of phosphorus saturation in the CaNPK soil profile suggests higher mobility and possibility of occurrence of losses of phosphorus from the profile of limed soil than from acidified soil. Therefore, management of phosphate fertilizers on permanently limed sandy soils requires the optimisation of phosphorus doses to a greater degree corresponding to the actual take-off of the element with crop. An additional finding of the study was evidence of the possibility of re-estimating contents of bioavailable phosphorus and, as a consequence, the degree of phosphorus saturation with Mehlich3 method in strongly acid soil receiving $\mathrm{P}$ mineral fertilisers, which can make it difficult to use the test for fertiliser recommendation.
\end{abstract}

Keywords: liming, long-term experiment, phosphorus sorption, phosphorus saturation, Mehlich3

\section{INTRODUCTION}

Phosphorus is a component the bioavailability of which largely depends on soil pH (Barrow 2017). Agronomic soil phosphorus testing is often the only available information about the phosphorus soil status. Meanwhile, a change in soil $\mathrm{pH}$ can modify its sorption properties towards phosphorus, increasing or decreasing not only its bioavailability but also phosphorus release (Murphy and Sims 2012; Szara et al. 2017). An increase in soil $\mathrm{pH}$ causes the process of deprotonation, and leads to an increase in negatively charged surfaces in the soil, reducing the anion sorption properties including phosphates. On the other hand, an increase in the ionic strength of the soil solution and Ca concentration can counteract the unfavourable anion electrostatic effect resulting from liming (Curtin et al. 1993). High Ca soil content can increase the precipitation of Ca-P compounds, and decreases phosphorus solubility (Jokubauskaite et al. 2015). Liming reduces the content of $\mathrm{Al}$ and $\mathrm{Fe}$ ions, which in reaction with fertiliser phosphorus, are precipitated to sparingly soluble Fe-P and Al-P compounds. The precipitation of exchangeable $\mathrm{Al}^{3+}$ as polymeric hydroxy-Al cations may create new highly active phosphate adsorbing surface in soils (Haynes 1982). Due to this, the effect of liming and change in soil $\mathrm{pH}$ on phosphorus sorption properties and release of soil $\mathrm{P}$ is ambiguous. Research to date on these relations has been conducted especially in the surface soil layer and more often in laboratory conditions (Anjos and Rowell 1987; Sato and Comerford 2005; Gichangi and Mnkeni 2009; Broggi et al. 2011) than field conditions (Jokubauskaite et al. 2015, Szara et al. 2017, Simonsson et al. 2018). Meanwhile, phenomena occurring in deeper soil layers define the direction and intensity of transformations of phosphorus introduced with fertilisers related to leaching of this element (Andersson et al. 2016). Due to easy-drainage properties and low capacity of phosphorus retention, transfer of phosphorus to deeper layers of the profile and further to drainage waters can occur in sandy soil (Andersson 2013). Therefore, our study was based on a long-term experiment conducted since 1923 with the application of mineral fertilisation with or without lime. The objective of the study was the assessment of the effect of liming on the accumulation and release of $\mathrm{P}$ in reference to phosphorus sorption properties in the sandy soil profile. 


\section{MATERIALS AND METHODS}

The study has been carried out on a long-term fertilisation experiment (since 1923) at the Experimental Station of the Warsaw University of Life Sciences - SGGW in Skierniewice (Central Poland, $51^{\circ} 96^{\prime} \mathrm{N}, 20^{\circ} 16^{\prime} \mathrm{E}$ ). The soil is a Planosol (IUSS Working Group WRB 2015) with content of clay particles $(<0.002 \mathrm{~mm})$ in the following diagnostic horizons: $8 \%$ in the upper layer (Ap), 7\% in Et , and $16 \%$ in Bt. The average annual temperature and precipitation are $8^{\circ}$ and $520 \mathrm{~mm}$ respectively. In the experiment, plants were cultivated in an arbitrary rotation. The research employed treatments (three repetitions) with a mineral fertilisation system with liming - CaNPK or without liming - NPK. The annual doses of mineral fertilisers equalled $90 \mathrm{~kg} \mathrm{~N}$ (as ammonium nitrate), $26 \mathrm{~kg} \mathrm{P}$ (as superphosphate), and $91 \mathrm{~kg} \mathrm{~K} \cdot \mathrm{ha}^{-1}$ (as potassium chloride). On CaNPK treatments, liming was applied every 4 years in a dose of $1.43 \mathrm{t} \mathrm{Ca} \cdot \mathrm{ha}^{-1}$. The average phosphorus uptake by plants was $19 \mathrm{~kg} \cdot \mathrm{ha}^{-1}$ under CaNPK and $17,5 \mathrm{~kg} \cdot \mathrm{ha}^{-1}$ under NPK treatment.

Soil samples were collected in autumn after mustard (Sinapis alba) harvest in 2015 from the following diagnostic horizons: $A_{p}(0-0.25 \mathrm{~m}), E_{e t}$ $(0.25-0.50 \mathrm{~m})$, and $\mathrm{B}_{\mathrm{t}}(0.50-0.75 \mathrm{~m})$. Soil samples for chemical analysis were air-dried and sieved to $2 \mathrm{~mm}$.

The following was determined in the soil samples: $\mathrm{pH}$ in $1 \mathrm{M} \mathrm{KCl}(1: 2.5)$, total organic carbon (TOC) by means of a TOC-analyser, total content of soil phosphorus $\left(\mathrm{P}_{\mathrm{t}}\right)$ - after soil digestation in $\mathrm{HNO}_{3} /$ $\mathrm{HClO}_{4}$, and content of inorganic phosphorus $\left(\mathrm{P}_{\mathrm{i}}\right)$ after extraction in $0.5 \mathrm{M} \mathrm{H}_{2} \mathrm{SO}_{4}$. The content of soil organic phosphorus $\left(\mathrm{P}_{\mathrm{o}}\right)$ was estimated as a difference between $\mathrm{P}_{t}$ and $\mathrm{P}_{\mathrm{i}}$ (O'Halloran and Cade-Menun 2008). Bioavailable phosphorus content was determined by means of Eghner-Riehm's double lactate extraction $\left(\mathrm{P}_{\mathrm{DL}}\right)(\mathrm{PN}-\mathrm{R}-04023$ 1996) and dissolved reactive $\mathrm{P}$ (DRP) after water soil extraction (1:5) following centrifugation and vacuum-filtration $(<0.45 \mu \mathrm{m})$ (Sharpley et al. 2008).

The Mehlich3 method was applied to determine the content of $\mathrm{Ca}_{\mathrm{M} 3}, \mathrm{Mg}_{\mathrm{M} 3}, \mathrm{Al}_{\mathrm{M} 3}, \mathrm{Fe}_{\mathrm{M} 3}$, and $\mathrm{P}_{\mathrm{M} 3}$ (Ziadi and Sen Tran 2008) The content of amorphous (hydr)oxide form $\mathrm{Al}_{\text {ox }}, \mathrm{Fe}_{\text {ox }}$, and $\mathrm{P}_{\text {ox }}$ was determined by acid ammonium oxalate extraction (Schoumans 2000). The degree of phosphorus saturation (DSP) of soil was calculated as ratio $\left(\mathrm{mmol} \cdot \mathrm{kg}^{-1}\right): \mathrm{DPS}_{\mathrm{M} 3}=$ $\left[\mathrm{P}_{\mathrm{M} 3} / \mathrm{PSC}_{\mathrm{M} 3}\right] \times 100 \%$, where $\mathrm{PSC}_{\mathrm{M} 3}=\left(\mathrm{Al}_{\mathrm{M} 3}+\mathrm{Fe}_{\mathrm{M} 3}\right)$ (Khiari et al. 2000) and according to the Schoumans modification (2000) $\mathrm{DPS}_{\text {ox }}=\left(\mathrm{P}_{\mathrm{ox}} / \mathrm{PSC}_{\mathrm{ox}}\right) \times 100 \%$, where $\mathrm{PSC}_{\mathrm{ox}}=\left(\mathrm{Al}_{\mathrm{ox}}+\mathrm{Fe}_{\mathrm{ox}}\right)$.
For the assessment of phosphorus sorption properties, soil samples were equilibrated with graded phosphorus concentration ( 0 to $20 \mathrm{mg} \mathrm{P} \cdot \mathrm{dm}^{-3}$ as $\left.\mathrm{KH}_{2} \mathrm{PO}_{4}\right)$ in $0.01 \mathrm{M} \mathrm{CaCl}_{2}(1: 10)$ for 24 hours. After centrifuging at $3000 \mathrm{rpm}$ for $15 \mathrm{~min}$, and filtering, the phosphorus concentration in the supernatant solution was measured $\left(\mathrm{C}, \mathrm{mg} \cdot \mathrm{dm}^{-3}\right)$. The amount of $\mathrm{P}$ sorbed $\left(\mathrm{S}, \mathrm{mg} \cdot \mathrm{kg}^{-1}\right)$ by the soil was calculated as the difference between the amount of phosphorus in solution before and after equilibrium (Sharpley et al. 2008).

In all extracts, phosphorus concentration was determined by means of the molybdenum-blue ascorbic method (Sharpley et al. 2008), and content of Fe, Al, $\mathrm{Ca}$ i $\mathrm{Mg}$ by means of atomic absorption spectrometry (AAS).

Sorption isotherms were examined by Langmuir equation: $\mathrm{C} / \mathrm{S}=1 / \mathrm{kS}_{\max }+\mathrm{C} / \mathrm{S}_{\max }$, where $\mathrm{S}_{\max }$ is the sorption maximum $\left(\mathrm{mg} \cdot \mathrm{kg}^{-1}\right)$, and $\mathrm{k}$ is constant related to bonding energy of soil for $\mathrm{P}\left(\mathrm{dm}^{3} \cdot \mathrm{mg}^{-1}\right)$. A plot of $\mathrm{C} / \mathrm{S}$ versus $\mathrm{C}$ gives a straight line with the slope value equal to $1 / \mathrm{S}_{\max }$ and $1 / \mathrm{kS}_{\max }$ as the $\mathrm{y}$-axis intercept (Sharpley et al. 2008). Maximum buffering capacity $(\mathrm{MBC})$ is derived as: $\mathrm{MBC}=\mathrm{k} \mathrm{S}_{\max }$ (Holford and Mattingly 1976).

The data were also fitted to the Freundlich equation: $S=a_{F} C^{b F}$, where $a_{F}$ is the extent of $P$ adsorption $\left(\mathrm{mg} \cdot \mathrm{kg}^{-1}\right)$, and $\mathrm{b}_{\mathrm{F}}$ a constant corresponding to the degree of linearity between the solution equilibrium concentration and absorption $\left(\mathrm{mg} \cdot \mathrm{dm}^{-3}\right)$. A linear plot of $\log _{10} a_{F}$ versus $\log _{10} C$ yields $a_{F}$ and $b_{F}$ from the intercept and slope, respectively (Graetz and Nair 2000).

The suitability of sorption equations was based on coefficient of determination $\left(\mathrm{R}^{2}\right)$ values. One-way analysis of variance (ANOVA) at $\mathrm{P}<0.05$ was used for comparison of means for each soil horizon of treatments separately, and mean total contents of parameters in soil profiles of treatments (SPSS IMAGO 23).

\section{RESULTS}

Fertilisation applied for more than 90 years led to strong acidification of the soil with NPK treatment, where $\mathrm{pH}$ decreased with depth from 4.5 to 3.9. Also on CaNPK, treatment soil $\mathrm{pH}$ decreased with soil depth, although permanent liming permitted the maintenance of weakly acidic reaction throughout the profile ( $\mathrm{pH}$ 6.7-6.3) (Table 1).

Content of $\mathrm{Ca}_{\mathrm{M} 3}$ in CaNPK soil $\left(3235 \mathrm{mg} \cdot \mathrm{kg}^{-1}\right)$ significantly higher than in NPK soil $\left(2186 \mathrm{mg} \cdot \mathrm{kg}^{-1}\right)$ was a natural effect of the introduction of the component from lime. An increase in the content of $\mathrm{Ca}_{\mathrm{M} 3}$ in 
soil decreased with soil depth. Although no fertilisation with magnesium was applied in any of the treatments, content of $\mathrm{Mg}_{\mathrm{M} 3}$ was significantly higher in $\mathrm{A}_{\mathrm{p}}(57$ $\left.\mathrm{mg} \cdot \mathrm{kg}^{-1}\right)$ and $\mathrm{B}_{\mathrm{t}}\left(131 \mathrm{mg} \cdot \mathrm{kg}^{-1}\right)$ horizons of the CaNPK soil profile than in the analogical NPK soil horizons (15 and $78 \mathrm{mg} \cdot \mathrm{kg}^{-1}$, respectively).

In comparison to NPK treatment $\left(8.50 \mathrm{~g} \cdot \mathrm{kg}^{-1}\right)$, lime did not change the total content of TOC in CaNPK treatment $\left(8.48 \mathrm{~g} \cdot \mathrm{kg}^{-1}\right)$, but changed its distribution in the soil profile. In CaNPK soil, higher accumulation of TOC occurred in horizons $A_{p}$ and $\mathrm{E}_{\mathrm{et}}$, and in NPK soil it's greater transfer to layer B occurred.

Content of $\mathrm{P}_{t}$ decreased with depth in both soils, but in spite of the application of the same dose of $\mathrm{P}$ fertiliser, content of $P_{t}$ was significantly higher in the NPK (661 mg $\mathrm{kg}^{-1}$ ) than in the CaNPK soil profile (634 $\mathrm{mg} \cdot \mathrm{kg}^{-1}$ ) (Table 1). Higher differences in $\mathrm{P}_{\mathrm{t}}$ content were determined in analogical soil horizons of both soils. In the surface layer of NPK soil, content of $\mathrm{P}_{\mathrm{t}}\left(349 \mathrm{mg} \cdot \mathrm{kg}^{-1}\right)$ was $43 \%$ higher in comparison to the layer of CaNPK treatment (244 $\left.\mathrm{mg} \cdot \mathrm{kg}^{-1}\right)$. In the layer of $\mathrm{E}_{\mathrm{et}}$ soil, content of $\mathrm{P}_{\mathrm{t}}$ was $54 \%$ higher in CaNPK than in NPK treatment. Because the contribution of $\mathrm{P}_{\mathrm{i}}$ in $\mathrm{P}_{\mathrm{t}}$ in the surface soil layer of NPK treatment equalled $71 \%$, it can be presumed that the accumulation of unused by plants fertiliser phosphorus occurred in this particular horizon. A considerable reduction of the contribution of $\mathrm{P}_{\mathrm{i}}$ in $\mathrm{P}_{\mathrm{t}}$ with depth to $38 \%$ in $\mathrm{E}_{\mathrm{et}}$ and $20 \%$ in $\mathrm{B}_{\mathrm{t}}$ horizon suggests higher mobility of $\mathrm{P}_{0}$ than $\mathrm{P}_{i}$ in NPK soil profile. The contribution of $\mathrm{P}_{i}$ in $\mathrm{P}_{t}$ decreased with soil depth also on CaNPK treatment, although it was more even throughout the soil profile (54-40\%).

Irrespective of the applied study method, the content of bioavailable $\mathrm{P}$ decreased with depth in both soils (Table 2). The content of $\mathrm{P}_{\mathrm{DL}}$ on CaNPK treatment varied from 55 to $6 \mathrm{mg} \cdot \mathrm{kg}^{-1}$, and was significantly higher than the content in each diagnostic horizon of the NPK treatment profile (from 41 to $\left.2 \mathrm{mg} \cdot \mathrm{kg}^{-1}\right)$.

Content of $\mathrm{P}_{\mathrm{M} 3}$ (from 94 to $17 \mathrm{mg} \cdot \mathrm{kg}^{-1}$ in CaNPK, and from 133 to $14 \mathrm{mg} \cdot \mathrm{kg}^{-1}$ in the NPK soil profile) was higher than $\mathrm{P}_{\mathrm{DL}}$. In contrast to $\mathrm{E}_{\mathrm{et}}$ and $\mathrm{B}_{\mathrm{t}}$ horizons,
TABLE 2. Content of phosphorus and the degree of $\mathrm{P}$ saturation in soil profile

\begin{tabular}{|c|c|c|c|c|c|c|c|}
\hline \multirow[t]{2}{*}{ Treatment } & \multirow[t]{2}{*}{ Horizon } & \multirow[t]{2}{*}{$\mathrm{P}_{\mathrm{ox}}$} & & \multirow[t]{2}{*}{$\mathrm{P}_{\mathrm{DL}}$} & \multirow[t]{2}{*}{ DRP } & \multirow{2}{*}{\multicolumn{2}{|c|}{$\frac{\text { DPS }^{o x}}{\%}$}} \\
\hline & & & $\mathrm{mg} \cdot \mathrm{kg}^{-1}$ & & & & \\
\hline \multirow[t]{4}{*}{ CaNPK } & A & $210 \mathrm{a}$ & $94 \mathrm{a}$ & $55 \mathrm{~b}$ & $5.72 b$ & $24.8 b$ & $16.4 \mathrm{a}$ \\
\hline & $\mathrm{E}$ & $184 b$ & $41 \mathrm{~b}$ & $22 b$ & $1.81 \mathrm{~b}$ & $22.6 b$ & $7.2 b$ \\
\hline & $\mathrm{B}$ & $86 \mathrm{~b}$ & $17 \mathrm{a}$ & $6 \mathrm{~b}$ & $0.48 b$ & $7.5 \mathrm{~b}$ & $2.1 \mathrm{~b}$ \\
\hline & total & $479 \mathrm{~B}$ & $151 \mathrm{~A}$ & $84 \mathrm{~B}$ & $8.01 \mathrm{~B}$ & & \\
\hline \multirow[t]{4}{*}{ NPK } & $\mathrm{A}$ & $209 \mathrm{a}$ & $133 b$ & $41 \mathrm{a}$ & $5.35 \mathrm{a}$ & $22.6 \mathrm{a}$ & $19.6 \mathrm{~b}$ \\
\hline & $\mathrm{E}$ & $111 \mathrm{a}$ & $21 \mathrm{a}$ & $13 \mathrm{a}$ & $1.44 \mathrm{a}$ & $12.1 \mathrm{a}$ & $3.6 \mathrm{a}$ \\
\hline & $\mathrm{B}$ & $52 a$ & $14 \mathrm{a}$ & $2 a$ & $0.37 \mathrm{a}$ & $4.0 \mathrm{a}$ & $1.5 \mathrm{a}$ \\
\hline & total & $373 \mathrm{~A}$ & 168B & $56 \mathrm{~A}$ & $7.16 \mathrm{~A}$ & & \\
\hline
\end{tabular}

a, b, A, B-as in table 1 content of $\mathrm{P}_{M 3}$ in the surface layer of NPK soil was considerably higher $\left(133 \mathrm{mg} \cdot \mathrm{kg}^{-1}\right)$ than in CaNPK soil $\left(94 \mathrm{mg} \cdot \mathrm{kg}^{-1}\right)$.

Content of dissolved reactive phosphorus extracted with water solution (DRP) was the lowest of all of the determined bioavailable forms of phosphorus, and similarly as $\mathrm{P}_{\mathrm{DL}}$, it was usually higher in horizons of the CaNPK soil profile $\left(5.72-0.48 \mathrm{mg} \cdot \mathrm{kg}^{-1}\right)$ than in NPK soil (5.35-0.37 $\left.\mathrm{mg} \cdot \mathrm{kg}^{-1}\right)$.

Content of $\mathrm{P}_{\text {ox }}$ was significantly higher in the CaNPK soil profile $\left(479 \mathrm{mg} \cdot \mathrm{kg}^{-1}\right)$ than in NPK soil (373 $\mathrm{mg} \cdot \mathrm{kg}^{-1}$ ), and depending on treatments it was 2-3 times higher than content of $\mathrm{P}_{\mathrm{M} 3}$, and 6-7 times higher than content of $\mathrm{P}_{\mathrm{DL}}$. In CaNPK soil, $\mathrm{P}_{\mathrm{ox}}$ content in $\mathrm{A}_{\mathrm{p}}$ horizon constituted $86 \%$ of $\mathrm{P}_{t}$, and in $\mathrm{B}_{t}$ horizon $51 \%$. The contribution of $\mathrm{P}_{\text {ox }}$ in $\mathrm{P}_{t}$ in the analogical NPK soil horizons was considerably lower and equalled $63 \%$ and $31 \%$ respectively. This suggests that with depth in both of the studied treatments, the contribution of well-crystalline forms of phosphorus increased and was higher than in the NPK soil profile.

Sorption parameters for phosphorus determined based on Langmuir $\left(\mathrm{R}^{2}>0.989\right)$ and Freundlich 
TABLE 3. Phosphorus sorption parameters in soil profile

\begin{tabular}{|c|c|c|c|c|c|c|}
\hline \multirow[t]{3}{*}{ Treatment } & \multirow[t]{3}{*}{ Horizon } & \multicolumn{2}{|c|}{ Langmuir } & \multirow[t]{2}{*}{$\mathrm{MBC}$} & \multicolumn{2}{|r|}{ Freundlich } \\
\hline & & $\mathrm{S}_{\max }$ & $\mathrm{k}$ & & $a_{F}$ & $\mathrm{~b}_{\mathrm{F}}$ \\
\hline & & $\mathrm{mg} \cdot \mathrm{kg}^{-1}$ & $\mathrm{dm}^{3} \cdot \mathrm{mg}^{-1}$ & $\mathrm{dm}^{3} \cdot \mathrm{mg}^{-1}$ & $\mathrm{mg} \cdot \mathrm{kg}^{-1}$ & $\mathrm{dm}^{3} \cdot \mathrm{mg}^{-1}$ \\
\hline \multirow[t]{4}{*}{ CaNPK } & $\mathrm{A}$ & $38 \mathrm{a}$ & $0.281 \mathrm{a}$ & $11 \mathrm{a}$ & $14 \mathrm{a}$ & $0.313 \mathrm{a}$ \\
\hline & $E$ & $59 \mathrm{a}$ & $0.418 \mathrm{a}$ & $25 \mathrm{a}$ & $25 \mathrm{a}$ & $0.290 \mathrm{a}$ \\
\hline & $\mathrm{B}$ & $122 \mathrm{a}$ & $0.755 \mathrm{a}$ & $92 \mathrm{a}$ & $51 \mathrm{a}$ & $0.351 \mathrm{a}$ \\
\hline & total & $219 \mathrm{~A}$ & $1.455 \mathrm{~A}$ & $127 \mathrm{~A}$ & $90 \mathrm{~A}$ & $0.954 \mathrm{~A}$ \\
\hline \multirow[t]{4}{*}{ NPK } & $\mathrm{A}$ & $49 b$ & $0.392 b$ & $20 \mathrm{~b}$ & $20 \mathrm{~b}$ & $0.312 \mathrm{a}$ \\
\hline & $\mathrm{E}$ & $76 \mathrm{~b}$ & $0.539 \mathrm{~b}$ & $41 b$ & $32 b$ & $0.284 a$ \\
\hline & $\mathrm{B}$ & $148 b$ & $1.091 \mathrm{~b}$ & $161 \mathrm{~b}$ & $73 b$ & $0.372 \mathrm{a}$ \\
\hline & total & $273 B$ & $2.022 \mathrm{~B}$ & $223 B$ & $125 \mathrm{~B}$ & $0.968 \mathrm{~A}$ \\
\hline
\end{tabular}

$\mathrm{a}, \mathrm{b}, \mathrm{A}, \mathrm{B}-\mathrm{as}$ in table 1

sorption equations $\left(\mathrm{R}^{2}>0.975\right)$ are presented in Table 3. The maximum $\mathrm{P}$ sorption capacity $\left(\mathrm{S}_{\max }\right)$ assumed by the Langmuir sorption model increased with depth in both soils (respectively in CaNPK: 38-122 $\mathrm{mg} \mathrm{P} \cdot \mathrm{kg}^{-1}$ and M: $\left.49-148 \mathrm{mg} \mathrm{P} \cdot \mathrm{kg}^{-1}\right)$. Total $\mathrm{S}_{\max }$ in the CaNPK soil profile $\left(219 \mathrm{mg} \mathrm{kg}^{-1}\right)$ however was considerably lower than in the NPK $\left(273 \mathrm{mg} \cdot \mathrm{kg}^{-1}\right)$. Similar patterns were determined in reference to the $\mathrm{a}_{\mathrm{F}}$ parameter corresponding to the number of sorption sites for phosphorus in the Freundlich sorption model.

Values $\mathrm{k}$ from the Langmuir model suggest that the bonding energy of phosphorus is considerably higher in each diagnostic horizon in NPK soil $(0.392-$ $\left.1.091 \mathrm{dm}^{3} \cdot \mathrm{mg}^{-1}\right)$ than CaNPK $\left(0.281-0.755 \mathrm{dm}^{3} \cdot \mathrm{mg}^{-1}\right)$, and in both soils the bonding affinity to soil particles increased with depth. Freundlich $b_{F}$ coefficient also related to the bonding energy unlike to $\mathrm{k}$ did not show such substantial vertical variability in the profiles or between the analogical diagnostic horizons of the studied soils $(0.313-0.351$ for CaNPK and 0.312$0.372 \mathrm{dm}^{3} \cdot \mathrm{mg}^{-1}$ for NPK).

The ability of soil to counteract changes in $\mathrm{P}$ concentration the in soil solution as a result of $\mathrm{P}$ fertilisation, measured by maximum buffering capacity (MBC), was considerably higher in NPK than in CaNPK soil, and varied from $20 \mathrm{dm}^{3} \cdot \mathrm{mg}^{-1}$ in the surface layer to $161 \mathrm{dm}^{3} \cdot \mathrm{mg}^{-1}$ in the B horizon of NPK treatment. In analogical horizons of CaNPK soil, MBC adopted values of 11 and $92 \mathrm{dm}^{3} \cdot \mathrm{mg}^{-1}$ respectively.

The amount of (hydr)oxide aluminium extracted with Mehlicha3 extract $\left(\mathrm{Al}_{\mathrm{M} 3}\right)$ was higher (1.1-1.4 times) than that determined in the oxalate solution $\left(\mathrm{Al}_{\mathrm{ox}}\right)$, but their variability was similar. The amount of Al determined by means of both methods increased in the profile with soil depth, and in each horizon of NPK soil (15.7-28.7 mmol $\cdot \mathrm{kg}^{-1}$ for $\mathrm{Al}_{\mathrm{M} 3}$ and $14.2-24.1 \mathrm{mmol} \cdot \mathrm{kg}^{-1}$ for $\mathrm{Al}_{\mathrm{ox}}$ ) it was significantly higher than in CaNPK soil (14.4 $23.1 \mathrm{mmol} \cdot \mathrm{kg}^{-1}$ for $\mathrm{Al}_{\mathrm{M} 3}$ and $12.2-20.8 \mathrm{mmol} \cdot \mathrm{kg}^{-1}$ for $\mathrm{Al}_{\text {ox }}$ ).

Unlike in the case of aluminium, content of $\mathrm{Fe}_{\text {ox }}$ was from 3.2 to 8.5 times higher than content of $\mathrm{Fe}_{\mathrm{M} 3}$ in different soil horizons. Content of $\mathrm{Fe}_{\mathrm{M} 3}$ decreased, and that of $\mathrm{Fe}_{\mathrm{ox}}$ increased with soil depth. Total content of $\mathrm{Fe}_{\mathrm{M} 3}$ and $\mathrm{Fe}_{\mathrm{ox}}$ in NPK soil (4.9$2.0 \mathrm{mmol} \cdot \mathrm{kg}^{-1}$ for $\mathrm{Fe}_{\mathrm{M} 3}$ and $15.7-17.5 \mathrm{mmol} \cdot \mathrm{kg}^{-1}$ for $\mathrm{Fe}_{\mathrm{ox}}$ ) was significantly higher than in CaNPK soil (3.9-1.9 mmol $\cdot \mathrm{kg}^{-1}$ for $\mathrm{Fe}_{\mathrm{M} 3}$ and $15.0-16.2$ $\mathrm{mmol} \cdot \mathrm{kg}^{-1}$ for $\left.\mathrm{Fe}_{\mathrm{ox}}\right)$. The variability of contents of $\mathrm{Fe}_{\mathrm{M} 3}$ and $\mathrm{Fe}_{\mathrm{ox}}$ between analogical horizons of both analysed treatments was lower than for $\mathrm{Al}_{\text {ox }}$ and $\mathrm{Al}_{\mathrm{M} 3}$.

Total content of amorphous (hydr)oxide $\mathrm{Al}_{\text {ox }}$ and $\mathrm{Fe}_{\text {ox }}$ determined based on oxalate extraction ( $\mathrm{PSC}_{\mathrm{ox}}$ ) was higher than in the case of Mehlich3 extraction $\left(\mathrm{PSC}_{\mathrm{M} 3}\right)$. Both parameters however constituting a measure of phosphorus sorption capacity, similarly as $\mathrm{S}_{\max }$, were significantly higher in all horizons of NPK soil, and in both treatments they increased with depth.

The phosphorus saturation degree (DPS ${ }_{\text {ox }}$ ) determined based on oxalate extraction adopted higher values in the CaNPK (7.5-24.8\%) than NPK soil profile (4.0-22.6\%) (table 2). This suggests a higher possibility of losses of phosphorus from limed soil. This is also confirmed by $\mathrm{DSP}_{\mathrm{M} 3}$ indices, but only in $\mathrm{E}_{\mathrm{et}}$ and $\mathrm{B}_{\mathrm{f}}$ horizons. Due to considerably higher content of $\mathrm{P}_{\mathrm{M} 3}, \mathrm{DPS}_{\mathrm{M} 3}$ is also higher in the surface layer of NPK than CaNPK soil. Among the analysed indices of release of $\mathrm{P}$ from soil (MBC, DRP, $\mathrm{k}, \mathrm{S}_{\max }$ ), only the $\mathrm{DSP}_{\mathrm{M} 3}$ parameter points to higher susceptibility of NPK soil to losses of P from the surface layer of soil than CaNPK soil.

\section{DISCUSSION}

The results of plant yielding and phosphorus use efficiency from superphosphate not presented in this article can be found in other papers concerning experiments in Skierniewice (Mercik and Stępień 2012; Stępień et al. 2018). According to those, in the analysed experiment, the reduction of the yield size on NPK (14-31\%) in comparison to CaNPK treatment depended on the plant species. Long-term P use efficiency from superphosphate averaged $31 \%$ on NPK and $37 \%$ on CaNPK soils. A smaller difference 
TABLE 4. Content of $\mathrm{Fe}$ and $\mathrm{Al}$ extracted with oxalate (OX) and Mehlich-3 (M3)

\begin{tabular}{|c|c|c|c|c|c|c|c|}
\hline Treatment & Horizon & $\mathrm{Al}_{\mathrm{ox}}$ & $\mathrm{Fe}_{\mathrm{ox}}$ & $\frac{\mathrm{PSC}_{\mathrm{ox}}}{\mathrm{mmol} \cdot \mathrm{kg}-1}$ & $\mathrm{Al}_{\mathrm{MB}}$ & $\mathrm{Fe}_{\mathrm{MB}}$ & $\mathrm{PSC}_{\mathrm{MB}}$ \\
\hline \multirow[t]{4}{*}{ CaNPK } & A & $12.2 \mathrm{a}$ & $15.0 \mathrm{a}$ & $27.2 \mathrm{a}$ & $14.4 \mathrm{a}$ & $3.9 \mathrm{a}$ & $18.4 \mathrm{a}$ \\
\hline & $\mathrm{E}$ & $11.2 \mathrm{a}$ & $15.2 \mathrm{a}$ & $26.2 \mathrm{a}$ & $15.1 \mathrm{a}$ & $2.8 \mathrm{~b}$ & $18.0 \mathrm{a}$ \\
\hline & $\mathrm{B}$ & $20.8 \mathrm{a}$ & $16.2 \mathrm{a}$ & $37.0 \mathrm{a}$ & $23.1 \mathrm{a}$ & $1.9 \mathrm{a}$ & $25.0 \mathrm{a}$ \\
\hline & total & $44.0 \mathrm{~A}$ & $46.4 \mathrm{~A}$ & $91.0 \mathrm{~A}$ & $52.6 \mathrm{~A}$ & $8.7 \mathrm{~A}$ & $61.3 \mathrm{~A}$ \\
\hline \multirow[t]{4}{*}{ NPK } & $\mathrm{A}$ & $14.2 \mathrm{~b}$ & $15.7 \mathrm{~b}$ & $29.9 b$ & $15.7 \mathrm{~b}$ & $4.9 \mathrm{~b}$ & $21.9 \mathrm{~b}$ \\
\hline & $\mathrm{E}$ & $13.3 \mathrm{~b}$ & $15.7 \mathrm{a}$ & $29.0 \mathrm{~b}$ & $16.6 \mathrm{~b}$ & $2.4 \mathrm{a}$ & $18.6 \mathrm{a}$ \\
\hline & $\mathrm{B}$ & $24.1 \mathrm{~b}$ & $17.5 \mathrm{~b}$ & $41.6 \mathrm{~b}$ & $28.7 \mathrm{~b}$ & $2.0 \mathrm{a}$ & $30.6 b$ \\
\hline & total & $51.7 \mathrm{~B}$ & $48.9 \mathrm{~B}$ & $100.0 \mathrm{~B}$ & $62.3 \mathrm{~B}$ & 9.3B & $71.3 \mathrm{~B}$ \\
\hline
\end{tabular}

in P use efficiency than crop yields in the analysed experiments explains higher of $\mathrm{P}_{t}$ content in the CaNPK soil profile than NPK. Excess of mineral fertiliser phosphorus particularly accumulated in the surface layer of NPK soil, but in CaNPK soil, a considerable part of $\mathrm{P}_{\mathrm{i}}$ was transferred to $\mathrm{E}_{\mathrm{et}}$ horizon.

An increase in biological activity, mineralisation, returns of crop residue, and stability of mineral-organic aggregates are the main processes determining the effect of liming on the content of soil organic matter (Kołodziejczyk et al. 2017). The net effect of these processes on soil organic matter stock depending on the fertilisation soil and climatic conditions is ambiguous (Paradelo et al. 2015). In the presented study, a higher amount of harvest residue in CaNPK treatment did not considerably change the content of TOC and $\mathrm{P}_{0}$. This suggests more intensive mineralisation of harvest residue than on NPK treatment. In the analysed soils, a considerably higher amount of $\mathrm{Ca}_{\mathrm{M} 3}$ and $\mathrm{Mg}_{\mathrm{M} 3}$ in CaNPK treatment could have reduced the mobility of organic compounds in comparison to NPK soil (Gao et al. 2014). As a result, content of TOC and $\mathrm{P}_{0}$ in $\mathrm{B}_{t}$ horizon of NPK was considerably higher than in CaNPK soil. The contribution of $\mathrm{P}_{\mathrm{o}}$ in $\mathrm{P}_{t}$ in $\mathrm{B}_{\mathrm{t}}$ horizon was as much as $80 \%$ in NPK and only $60 \%$ in CaNPK soil.

Values of parameters from sorption models can increase or decrease due to liming depending on soil conditions (Haynes 1982, Sato and Comerford 2005; Gichangi and Mnkeni 2009; Broggi et al. 2011). In our study, values of parameters related to the number of site, $\mathrm{P}$ sorption $\left(\mathrm{S}_{\max }\right)$ and bonding energy $(\mathrm{k})$ from Langmuir and $\mathrm{a}_{\mathrm{F}}$ from Freundlich model were considerably higher throughout the NPK than CaNPK profile. This particularly resulted from considerably higher content of poorly crystallined (hydr)oxide Al and $\mathrm{Fe}$ obtained with oxalate and Mehlich3 method which are the main phosphate adsorbents in sandy soil (Lookman et al. 1995). Contrary to our study results, in multi-annual experiments in Sweden, liming caused no substantial changes in the content of oxalate-extractable $\mathrm{Al}$ and $\mathrm{Fe}$ (Simonsson et al. 2018). Already after 23 months following the application of lime, Anjos et al. (1987) determined a reduction of the number of sites for $\mathrm{P}$ sorption as a result of crystallisation of $\mathrm{Al}$ (hydr)oxide in soil.

The observed decrease in bonding energy related to a decrease in the number of sorption sites in the soil is a pattern confirmed in the results of research by Sato and Comerford (2005). A decrease in the value of parameter $\mathrm{k}$ (by 28\%) throughout the profile of CaNPK in comparison to NPK soil was higher than the decrease in the value of $\mathrm{S}_{\max }$ (by $20 \%$ ), $\mathrm{PSC}_{\text {ox }}$ (by $9.3 \%$ ), and $\mathrm{PSc}_{\mathrm{M} 3}$ (by 14\%). This can confirm the theory that an increase in soil $\mathrm{pH}$ attributed to competition of hydroxyl $\left(\mathrm{OH}^{-}\right)$concentration with phosphate ions for specific sorption sites, and an increase in deprotonation intensifies electrostatical repulsation of $\mathrm{P}$ weakening the affinity to mineral surfaces (Curtin et al. 1993). Therefore, even in the case of an increase in phosphorus capacity as a result of liming, a decrease in bonding energy is observed (Broggi et al. 2011). According to Holford and Mattingly (1976) the cooperation of the number of sites $\left(\mathrm{S}_{\max }\right)$ and their affinity to phosphorus $(\mathrm{k})$ decides about the maximum buffering capacity (MBC) of soil. The MBC value suggests the ability of soil to retain constant $\mathrm{P}$ concentration in the soil solution both in the case of its exhaustion and application under the condition of maintaining constant value of $\mathrm{S}_{\max }$. Therefore, the MBC value is of environmental and agronomic importance, because it can be used for the assessment of the possibilities of supply and immobilisation of phosphorus in the soil. In our study, there is significantly lower MBC value in each CaNPK horizon than in NPK soil, making it more susceptible to phosphorus loss in the case of further application of phosphorus fertilisers. MBC values indicate that $\mathrm{B}_{t}$ soil horizon can counteract the transfer of 1.8 times smaller mass of phosphorus to drainage water from CaNPK than NPK soil. Therefore, particularly in limed soils, doses of phosphorus 
fertilisers should to a greater degree correspond with the actual take-off of $\mathrm{P}$ with crop.

The value of $a_{F}$ less than 0.40 suggests that adsorption rather than precipitation is responsible for the retention of phosphorus in the soil of both analysed treatments (Castro and Torrent 1998). However, a higher value of parameter $b_{F}(0.313$ $\left.\mathrm{dm}^{3} \cdot \mathrm{mg}^{-1}\right)$ than parameter $\mathrm{k}\left(0.281 \mathrm{dm}^{3} \cdot \mathrm{mg}^{-1}\right)$ in the surface layer of CaNPK soil suggests that precipitation of $\mathrm{P}$ in this soil horizon largely contributes to the process of sorption of the component (Hussain et al. 2006). Considerable content of $\mathrm{Ca}_{\mathrm{M} 3}$ in this soil layer can contribute to the precipitation of $\mathrm{Ca}-\mathrm{P}$ observed in limed soils (Jokubauskaitë et al. 2015).

One of the effects of an increase in soil $\mathrm{pH}$ as a result of liming is an increase in the bioavailability of $\mathrm{P}$ for crop production (Sato and Comerford 2005; Jokubauskaitë et al. 2015, Goulding 2016, Szara et al. 2017). Also in our study, in spite of identical doses of phosphorus, content of $\mathrm{P}_{\text {ox }}$ and $\mathrm{P}_{\mathrm{DL}}$ was higher in CaNPK soil horizons than in NPK soil. Because oxalate solution extraction releases not only P absorbed on soil particles, but also a part of organic phosphorus, content of $\mathrm{P}_{\text {ox }}$ is usually more approximate to the total than bioavailable amount of this element (Guo and Yost 1999). Lower content of $\mathrm{P}_{\text {ox }}$ and its contribution in $P_{t}$ suggests an increase in the content of well-crystalline form of $\mathrm{P}$ and lower risk of release of $\mathrm{P}$ in NPK than in CaNPK soil.

Contrary as for $\mathrm{P}_{\mathrm{DL}}$, considerably higher content of available $P$ in the surface layer of NPK $\left(133 \mathrm{mg} \cdot \mathrm{kg}^{-1}\right)$ than CaNPK (94 $\left.\mathrm{mg} \cdot \mathrm{kg}^{-1}\right)$ soil was obtained by means of the Mehlich3 method. A considerable effect of soil $\mathrm{pH}<5.5$ on the growth of phosphorus extracted with M3 solution (by 45-55\%) was evidenced by Penn et al. (2018). According to the authors, the capacity of M3 solution to release P from hardly accessible bonds of Al-P in conditions of strong soil acidification is probably the effect of both a change in the form of $\mathrm{P}$ in soil and properties of the extractor itself. This particularly concerns the intensity of the deprotonation/protonation reaction and capacity of $\mathrm{F}^{-}$to complex Al promoting dissolution of Al-P minerals (e.g. variscite, gibbsite). The specificity of Mehlich-3 solution in contrast to oxalate solution allows for extraction of only less stable forms of iron. Therefore according to Shang et al. (2013), in the case of application of those methods for risk assessment of soil, it is important to consider its mineralogical composition. Mineralogical composition was not the subject of our study, but perhaps it was the cause of the fact that unlike in the case of $A_{p}$ horizon, content of $\mathrm{P}_{\mathrm{M} 3}$ similarly as $\mathrm{P}_{\mathrm{DL}}$ and $\mathrm{P}_{\mathrm{ox}}$ in the $\mathrm{E}_{\mathrm{et}}$ and $\mathrm{B}_{\mathrm{t}}$ soil horizon was considerably higher in CaNPK than NPK soil.

Research by Shang et al. (2013) and Penn et al. (2018) also permits better understanding of the differences obtained in the content of $\mathrm{Al}_{\mathrm{ox}}$ and $\mathrm{Al}_{\mathrm{M} 3}$ in different soil conditions. In the majority of soils, the ratio $\mathrm{Al}_{\mathrm{M} 3}: \mathrm{Al}_{\mathrm{ox}}$ equals 0.8 (Sims et al. 2002, Pizzeghello et al. 2014). In our research, the content of $\mathrm{Al}_{\mathrm{M} 3}$ in all horizons was higher by approximately 10-20\% in comparison to the content of $\mathrm{Al}_{\text {ox }}$. Similar results were obtained by Penn et al. (2006) in the soils of Virginia.

Doubts resulting from the interpretation of study results due to higher content of $\mathrm{P}_{\mathrm{M} 3}$ and value of $\mathrm{DPS}_{\mathrm{M} 3}$ in the surface layer of NPK than CaNPK soil are largely eliminated by the observed values of DRP. Water used for its extraction does not interact with unavailable forms of P. Therefore DRP is not only a measure of readily available $\mathrm{P}$, but also a good predictor of the potential loss of $\mathrm{P}$ from soil which usually shows a strong correlation with $\mathrm{DSP}_{\mathrm{M} 3}$ and DSP $_{\text {ox }}$ (Sims et al. 2002, Penn et al. 2006, Szara et al. 2018). The content of DRP confirmed higher susceptibility of CaNPK soil in all profiles to release of $\mathrm{P}$ than NPK soil, as suggested by content $\mathrm{P}_{\mathrm{DL}}$ and $\mathrm{P}_{\mathrm{ox}}$, and $\mathrm{DSP}_{\mathrm{ox}}$.

\section{CONCLUSIONS}

Liming applied in combination with mineral fertilisers reduces sorption capacity throughout the sandy soil profile particularly as a result of fixation of amorphous of (hydr)oxide $\mathrm{Al}$ and $\mathrm{Fe}$ to more crystalline forms. This leads to higher mobility of the balance surplus in the soil profile, causing an increase in the content of oxide-extractable $\mathrm{P}$, bioavailable $\mathrm{P}$ and dissolved reactive phosphorus in water promoting release of $\mathrm{P}$. Therefore management of the phosphate fertilisers on permanently limed sandy soil requires the optimisation of $\mathrm{P}$ doses to a greater degree corresponding to the actual take off of the component with yield to minimise the risk of losses of soil phosphorus.

An additional study finding is also the determination of the possibility to re-estimate contents of bioavailable phosphorus, and as a consequence, the degree of phosphorus saturation with Mehlich-3 test in strongly acid soil receiving $\mathrm{P}$ mineral fertilisers, which can make it difficult to use the test for fertiliser recommendation. 


\section{REFERENCES}

Andersson H., Bergström L., Djodjic F., Ulen B., Kirchmann H., 2016. Lime placement on subsoil as strategy to reduce phosphorus leaching from agricultural soil. Soil Use and Management 32: 381-389.

Andersson H., Bergström L., Djodjic, F., Ulen B., Kirchmann H., 2013. Topsoil and subsoil properties influence phosphorus leaching from four agricultural soils. Journal of Environmental Quality 42: 455-463.

Anjos J.T., Rowell D.L., 1987. The effect of lime on phosphorus adsorption and barley growth in three acid soils. Plant and Soil 103: 75-82.

Barrow N.J., 2017. The effects of $\mathrm{pH}$ on phosphate uptake from soil. Plant and Soil 410: 401-410.

Broggi F., Oliveira A.D., Freire F.J., Freire M.D.S., Nascimento C.D., 2011. Phosphate capacity factor in mineralogically different soils in Pernambuco and the influence of $\mathrm{pH}$ on the maximum capacity of adsorption. Ciênciae Agrotechnologia 35: 77-83.

Castro B., Torrent J., 1998. Phosphate sorption by calcareous Vertisols and Inceptisols as evaluated from extended P-sorption curves. European Journal of Soil Science 49: 661-667.

Curtin D., Syers J.K, Bolan N.S., 1993. Phosphate sorption by soil in relation to exchangeable composition and $\mathrm{pH}$. Australian Journal of Soil Research 31: 137-149.

IUSS Working Group WRB, 2015. World Reference Base for Soil Resources 2014, update 2015. International soil classification system for naming soils and creating legends for soil maps. World Soil Resources Reports No. 106. FAO, Rome.

Gao Y., Zhu B., He N., Yu G., Wang T., Chen W., Tian J., 2014. Phosphorus and carbon competitive sorption and associated non-point loss respond to natural rainfall events. Journal of Hydrology 517: 447-457.

Gichangi E.M., Mnkeni P.N., 2009. Effects of goat manure and lime addition on phosphate sorption by two soils from the Transkei region, South Africa. Communications in Soil Science and Plant Analysis 40: 21-22.

Goulding K.W., 2016. Soil acidification and the importance of liming agricultural soils with particular reference to the United Kingdom. Soil Use and management 32: 390-399.

Graetz D.A., Nair V.D., 2000. Phosphorus sorption isotherm determination. [In:] Methods of Phosphorus Analysis for Soil, Sediments, Residual and Water (Pierzynski G.M., Editor). Methods of phosphorus analysis for soils, sediments, residuals, and waters. Southern Cooperative Series Bulletin 396: 3538.

Guo F., Yost R S.Y., 1999. Quantifying the available soil phosphorus pool with the acid ammonium oxalate method. Soil Science Society of America Journal 63: 651-656.

Haynes R.J., 1982. Effects of liming on phosphate availability in acid soil. Plant and Soil 68: 289-308.

Holford I.C., Mattingly G.E.G., 1976. A model for the behavior of labile phosphate in soil. Plant and Soil 44: 219-229.

Hussain A., Ghafoor A., Murtaza G., 2006. Use of model for phosphorus adsorption on some sodic soil of Punjab. International Journal of Agriculture and Biology 2: 241-248.

Jokubauskaitë I., Karčauskienë D., Antanaitis Š., Mažvila J., Šlepetienë A., Končius D., Piaulokaitë-Motuzienë L., 2015. The distribution of phosphorus forms and fractions in Retisol under different soil liming management. Zemdirbyste-Agriculture 102: 251-256.

Khiari L., Parent L.E., Pellerin A., Alimi A.R.A., Tremblay C., Simirad R.R., Fortin J., 2000. An agri-environmental phosphorus saturation index for acid coarse-textured soils. Journal of Environmental Quality 29: 1561-1567.

Kołodziejczyk M., Antonkiewicz J., Kulig B., 2017. Effect of living mulches and conventional methods of weed control on weed occurrence and nutrient uptake in potato. International Journal of Plant Production 11: 275-284.

Lookman R., Vandeweert R.N., Merckx R., Vlassak K., 1995. Geostatistical assessment of regional distribution of phosphate sorption capacity parameters (Feox and Alox) in northern Belgium. Geoderma 66: 285-29.

Mercik S., Stępień W., 2012. Effect of nitrogen on crop yield as influenced by soil $\mathrm{pH}$ and fertilization with farmyard manure. Ecological Chemistry and Engineering A.19: 105-111.

Murphy N.C., Sims J.T., 2012., Effects of Lime and phosphorus application on phosphorus runoff risk. Water Air and Soil Pollution 223: 101-111.

O'Halloran I.P., Cade-Menun B.J., 2008. Total and organic phosphorus. [In:] Soil Sampling and Methods of Analysis (Carter M.R., Gregorich E.G., Editors). CRC Press, Boca Raton: 265-291.

Paradelo R., Virto I., Chenu C., 2015. Net effect of liming on soil organic carbon stocks: A review. Agriculture, Ecosystems and Environment 202: 98-107.

Penn Ch.J, Mullins G.L, Zelazny L.W., Sharpley A.N., 2006. Estimating dissolved phosphorus concentrations in runoff from three physiographic regions of Virginia Soil Science Society of America Journal 70: 1967-1974.

Penn Ch.J., Rutter E.B., Arnall D.B., Camberato J., Williams M., Watkins P., 2018. A discussion on Mehlich-3 phosphorus extraction from the perspective of governing chemical reactions and phases: impact of soil pH. Agriculture 8: 106.

Pizzeghello D., Berti A., Nardi S., Morari F., 2014. Phosphorusrelated properties in the profiles of three Italian soils after long-term mineral and manure applications. Agriculture, Ecosystems and Environment 189: 216-228.

PN-R-04023 1996. Chemical and agricultural analysis-determination of the content available phosphorus in mineral soil. Polish Standards Committee, Warszawa.

Sato S., Comerford N.B., 2005. Influences of soil pH on inorganic phosphorus sorption and desorption in a humid Brazilian ultisol. Revista Brasileira de Ciência do Solo 29: 685-694.

Schoumans O.F., 2000. Determination of the degree of phosphorus saturation in non-calcareous soils. [In:] Methods of Phosphorus Analysis for Soil, Sediments, Residual and Water (Pierzynski G.M., Editor). Southern Cooperative Series Bulletin 396: 31-34.

Shang C.W., Zelazny L., Berry D.F., Maguire R.O., 2013. Orthophosphate and phytate extraction from soil components by common soil phosphorus tests. Geoderma 209: 22-30.

Sharpley A.N., Kleinman P.J.A., Weld J.L., 2008. Environmental Soil Phosphorus Indices. [In:] Soil Sampling and Methods of Analysis (Carter M.R., Gregorich E.G., Editors). CRC Press, Boca Raton: 141-159.

Simonsson M., Östlund A., Renfjäll L., Sigtryggsson Ch., Börjesson G., Kätterer T., 2018. Pools and solubility of soil phosphorus as affected by liming in long-term agricultural field experiments. Geoderma 315: 208-219. 
Sims J.T., Maguire R.O., Leytem A.B., Gartley K.L., Pautler M.C., 2002. Evaluation of Mehlich3 as an agri-environmental soil phosphorus test for the mid-Atlantic United States of America. Soil Science Society of America Journal 66: 2016-2032.

Stępień W., Sosulski T., Szara E., 2018,. Interaction between mineral and organic fertilization in long-term experiments in Skierniewice. [In:] Long-term experiments in agricultural studies in Poland (Marks M., Jastrzębska M., Kostrzewska M.K., Editors) UMW: 7-27.

Szara E., Sosulski T., Szymańska M., Stępień W., 2017. Phosphate sorption and P soil-test in sandy loam soil as affected by manure and lime applications in a long-term fertilization experiment. Fresenius Environmental Bulletin 26: 3191-3199.
Szara E., Sosulski T., Szymańska M., Szyszkowska K., 2018. Usefulness of Mehlich-3 test in the monitoring of phosphorus dispersion from Polish arable soils. Environmental Monitoring and Assessment 190: 298.

Ziadi N., Sen Tran T., 2008. Mehlich3-extractable elements. [In:] Soil Sampling and Methods of Analysis (Carter M.R., Gregorich E.G., Editors). CRC Press, Boca Raton: 81-87.

Received: December 6, 2018

Accepted: March 6, 2019

Association editor: B. Rutkowska

\section{Wpływ wieloletniego wapnowania na sorpcję fosforu w glebie lekkiej}

Streszczenie: Celem badań była ocena wpływu systematycznego wapnowania na akumulację i mobilność fosforu w odniesieniu do właściwości sorpcyjnych wobec fosforu w profilu gleby lekkiej. Badania przeprowadzono w oparciu o kombinacje z mineralnym nawożeniem stosowanym z wapnowaniem (CaNPK) lub z jego pominięciem (NPK) w wieloletnim doświadczeniu nawozowym prowadzonym od 1923 roku w Skierniewicach (Centralna Polska). Przy stosowaniu jednakowych dawek nawozów mineralnych zawartość fosforu ogólnego w profilu gleby niewapnowanej (NPK) była większa niż w profilu gleby wapnowanej (CaNPK). Wskaźniki oceny pojemności sorpcyjnej oraz siły wiązania fosforu wyznaczone opierając się o model Langmuira i Freundlicha były istotnie mniejsze w profilu gleby CaNPK niż NPK. Było to spowodowane przede wszystkim mniejszą zawartością słabo skrystalizowanych form tlenków i hydroksytlenków glinu i żelaza w profilu gleby CaNPK niż NPK. Większa zawartość form słabo skrystalizowanych oraz fosforu biodostępnego oznaczanego metodą Egnera-Riehma (DL) oraz fosforu rozpuszczalnego w wodzie wskazuje na większą mobilność i możliwość wystąpienia strat fosforu z profilu gleby wapnowanej niż z gleby zakwaszonej. Dlatego szczególnie na glebach systematycznie wapnowanych konieczna jest ścisła kontrola dawek nawozów fosforowych na podstawie faktycznego wynoszenia tego składnika z plonem. Dodatkowym efektem przeprowadzonych badań było wykazanie możliwości przeszacowania zawartości fosforu dostępnego, a w konsekwencji również stopnia wysycenia fosforem przy użyciu metody Mehlicha3 w glebie silnie zakwaszonej w wyniku stosowania nawożenia mineralnego. Fakt ten może utrudniać używanie tego testu do celów agronomicznych i środowiskowych.

Słowa kluczowe: wapnowanie, wieloletnie doświadczenie nawozowe, sorpcja fosforu, wysycenie gleby fosforem, Mehlich3 